\title{
WRIGHT v. ROCKEFELLER AND LEGISLATIVE GERRY- MANDERS: THE DESEGREGATION DECISIONS PLUS A PROBLEM OF PROOF
}

The historical and present significance of the electoral gerrymander ${ }^{1}$ - the manipulation of the configuration and thereby the character of the population of political districts ${ }^{2}$-parallels that of the malapportionment of voting districts, ${ }^{3}$ for both are methods by which legislatures may vest or frecze unchallengeable electoral power in favored groups. But because gerrymandered districts may often be based on such factors as race, religion, party affiliation, or nationality, challenges to such districting on the ground of equal protection present considerations distinct from those of the now more familiar complaint against legislative districts of unequal population. The case of $W$ right $v$. Rockefeller ${ }^{4}$ represents the first of the post-Baker $v$. Carr ${ }^{6}$ challenges to the power of legislatures to create political districts that conform to racial and ethnic lines. ${ }^{6}$ Although two members of the three judge panel in $W$ right believed that

1. The word has its roots in early American history, having been coined in $\mathbf{1 8 1 2}$ to describe a salamander shaped district drawn for the eastern shore of Massachusetts during the administration of Governor Elbridge Gerry. "How's that for a salamander?" the party who first noted the resemblance of the district to the reptile was reported to have asked. "Better call it a Gerrymander" was the recorded retort which made etymological history. See Tabor, The Gerrymandering of State and Federal Legislative Districts, 16 Mfp. L. REv. 277, 278 n.6 (1956).

In some accounts, the dialogue is reported as having occurred between a Massachusetts newspaper editor, Benjamin Russell, and the famous American portraitist, Gilbert Stuart, with credit for the word going to Russell. 2 WebSTER's INTERsational Dictio:iary 1052 (2d ed. 1957).

2. Although the term has been used to describe situations on the basis of a comparative survey of populations of like districts, it is restricted in this Note to situations involving districts varying greatly in physical form from ordinary geometric norms.

3. The term "malapportionment" is used to refer to the situation alluded to in note 2 supra. For examples of the difference between malapportionment and gerrymander, sce Lewis, Legislative Apportionnent and the Federal Courts, 71 HARv. L. REv. 1057, 1059, 1060 (1958).

4. 211 F. Supp. 460 (S.D.N.Y. 1962), Notice of Appeal to the Supreme Court filed, January, 1963. See also Honeywood v. Rockefeller, Civil No. 62C243, E.D.N.Y., denial of preliminary injunction aff'd, 371 U.S. 1 (1962). The latter case involves a challenge similar in its constitutional nature to Wright, differing in its specific fact setting.

5. 369 U.S. 186 (1962).

6. The Tuskeegee gerrymander case, Gomillion v. Lightfoot, 364 U.S. 339 (1960), was regarded by the trial panel in Wright as sufficient to dispose of the question of its justiciability under both the fourteenth and fifteenth amendments. W'right may not be a significant aftermath of Baker v. Carr in terms of the formal applicability or non-applicability of the "political question" doctrine, but it is a test of the extent to which Balscr has triggered "a sharp increase in judicial readiness to inquire into the architecture of the legislative establishment." Pollak, Judicial Power and "the Politics of the Pcople," 72 YALE L.J. 81, 82 (1962). 
states may not draw voting district lines on the basis of race, or national origin, the case may have left legislatures almost entirely free to draw voting district lines on any criteria so long as the population disparity between districts does not exceed a figure in and of itself subject to constitutional attack. For the court left the guidelines for proving racial or ethnic districting sufficiently undefined as to make a showing of state districting on the basis of race or ethnic factors extremely problematical. As is indicated in the three separate opinions in Wright, the case presents not only the question of the constitutionality under the Fourteenth and Fifteenth Amendments of racially and ethnically drawn district lines but also the perhaps more difficult evidentiary question of how parties prove that the state has so acted.

Following the 1960 census, the number of Congressmen allotted to the State of New York was decreased by two. ${ }^{7}$ In accordance with a practice of respecting county boundary lines within the City of New York and minimizing the number of legislative districts composed of fractional parts of two different counties, $^{8}$ the 1961 New York Apportionment Act reduced the Congressional delegation of New York County (the Borough of Manhattan) from six to four. ${ }^{9}$ Plaintiffs in the Wright case, Negro and Puerto Rican residents of the four Manhattan congressional districts, established the following about the new political alignment of the Borough:

The decision in Baker would seem to have laid to rest the formal question of justiciability of congressional, as well as state legislative, apportionments. See 369 U.S. at 232; Black, Inequities in Districting for Congress: Baker v. Carr and Colgrove v. Grech, 72 YALE L.J. 13 (1962). But see Wesberry v. Vandiver, 206 F. Supp. 276 (N.D. Ga، 1962), criticized in Comment, 63 Coluar. L. Rev. 98 (1963).

7. See Interum Report of tae Jornt Legislative Comaittee on Reaproktionsent, N.Y. Sess. Law 1961, Second Extra Session, pp. 63, 65. [Hereinafter cited as N.Y. Rerokr.]

8. The representational pattern of New York State's districting schemes is county oriented. The federal panel which upheld the apportionment of the New York State Legislature did so largely in light of its recognition of the historic importance the state had placed on making its counties as politically independent and self containcd as possible. W.M.C.A. v. Simon, 208 F. Supp. 368, 376 (S.D.N.Y. 1962) ("In New York, the county is a classic unit of governmental organization and administration."). This was done in spite of substantial population variances among the various state legislative seats. $208 \mathrm{~F}$. Supp. at 378-79. On the latter point, see generally Silva, Apportionment of the Ncw York Sckatc, 30 Fordian L. Rev. 595 (1962); Silva, Apportionment of the New York Asscmbly, 31 FoRdHAMr L. REv. 1 (1962). For a discussion of the constitutionality of New York's apportionment, see Comment, Baker v. Carr and Legislative Apportionments: A Problcm of Standards, 72 YALE L.J. 968, 1019-27 (1963).

The sole descriptive appendix to the bill setting up the State's congressional distriets described the congressional districts in terms of the relation of each to the county or counties they were in N.Y. Sess. Laws 1961, Second Extra Session, ch. 980, Exhibit B. Of the nineteen congressional districts set within the City of New York, only one contains fractional parts of two different boroughs ... with all the others but the one which contains the Borough of Richmond-not in and of itself large enough to merit its own congressional seat . . . being set entirely within individual boroughs. Within Manhattan, the four congressional districts were self-contained in accord with the historical state pattern of counties functioning as independent representational entities.

9. The reduction was not challenged by the plaintiffs. Plaintiffs' Trial Memorandum, p. 2. 
1. With a Borough population established by the census as 37.7 per cent non-white and Puerto Rican, ${ }^{10}$ one of the newly fashioned districts, the 17 th, contained a population 94.9 per cent white. An adjacent district, the 18th, contained a population 86.6 per cent non-white and Puerto Rican. ${ }^{11}$

2. The 17 th District was 12 per cent-15 per cent smaller in population than any of the other Manhattan districts, with all of the others roughly the same size. ${ }^{12}$.

3. The 17th. District was incapable of expansion in any direction without incorporating a non-white population concentration heavier than that found on the inside of its border lines. ${ }^{13}$

4. Through three-successive apportionment acts, the 17th District had developed from an essentially rectangular figure to an irregular 31 sided figure carved out of the middle of the Borough. ${ }^{14}$ Starting with 1941 Apportionment Act, the beginning of a conformance with racial residency patterns was shown, as the configuration of the District began to assume an irregular shape and approximate the press of Manhattan's non-white population. The previously straight northerly border of the District became somewhat jagged in 1941, and finally assumed the step shaped pattern in 1951 that was retained by the 1961 act.15

10. The $\mathbf{1 9 6 0}$ census divided the ethnic groups of New York City into only two classes: "white" and "non-white and Puerto Rican" See 211 F. Supp. at 472 (Murphy, J., dissenting).

11. The four Manhattan Congressional Districts were broken down as follows in terms of their racial make-ups and relative populations:

\begin{tabular}{|c|c|c|c|c|c|}
\hline District & $\begin{array}{l}\text { Total } \\
\text { Popula- } \\
\text { tion }\end{array}$ & \multicolumn{2}{|c|}{$\begin{array}{c}\text { White } \\
\text { Population: } \% \text { of District }\end{array}$} & \multicolumn{2}{|c|}{$\begin{array}{l}\text { Non-White and Puerto } \\
\text { Rican Origin } \\
\text { Population } \% \text { of District }\end{array}$} \\
\hline 17th & 382,320 & 362,668 & $94.9 \%$ & 19,652 & $5.1 \%$ \\
\hline 18th & 431,330 & 59,216 & $13.7 \%$ & 372,114 & $86.3 \%$ \\
\hline 19th & 445,175 & 318,223 & $71.5 \%$ & 126,952 & $28.5 \%$ \\
\hline 20 th & 439,456 & 318,482 & $72.5 \%$ & 120,974 & $27.5 \%$ \\
\hline Cot & 698,281 & $1,058,589$ & $62.3 \%$ & 639,692 & $37.7 \%$ \\
\hline
\end{tabular}

211 F. Supp. at 472 (Murphy, J., dissenting).

12. Ibid.

13. See $211 \mathrm{~F}$. Supp. at 470 (Feinberg, J., concurring). In the one instance where a predominantly white area adjacent to the 17th Congressional District had not been incorporated in it, the plaintiffs showed that the region did not have a very large population and that it had recently been set aside by the City of New York for a public-housing project. Record, p. 165. See Board of Estrurate Resolution of the City of New Yoss, CALENDAR No. 288. Figures for the racial composition of such projects already in existence in Manhattan currently stand at 73.4\% non-white. See Letter from New York Housing Authority introduced as Exhibit 7. Record, p. 237.

14. The 1961 apportionment, however, reduced the number of lines in the 17th Congressional District from 49 to 31 . $211 \mathrm{~F}$. Supp. at $470 \mathrm{n} .8$.

15. See Plaintiffs' Post-Trial and Reply Memorandum, pp. 17-20. The westerly border of the 17th Congressional District, the only one which the 1961 Apportionment Act did not alter, remained somewhat jagged even though a general straightening of the lines would not measurably have altered the racial composition of the 17th. One of the Wright judges took this to show an absence of a legislative purpose to draw the lines on a racial basis. 
5. Although the district lines of the 17 th district on the eastern border became somewhat more symmetrical as a result of the addition of two sections in 1961, the two major sections added were the two remaining population concentrations having the Borough's highest percentage of white voters. ${ }^{10}$ In addition, two square blocks whose racial character had changed drastically from the time of the 1951 apportionment and was 44.5 per cent Negro and Puerto Rican in 1961 were eliminated from the 17 th district. ${ }^{17}$ This excission and the addition of the two predominantly white neighborhoods were the only changes made in the 17th District by the 1961 Apportionment Act.

The three judge court denied relief to the plaintiffs, each judge writing a separate opinion. Because the opinion of Judge Moore does not explicitly separate the evidentiary question from the constitutional issue, it is not clear whether he believed that legislative districting on the basis of race or national origin was constitutionally permissible. His treatment of the facts of the case, however, suggests that racial or ethnic districting is not in and of itself impermissible unless accompanied by an additional showing of harm to the isolated groups. Judge Moore's discussion of the population disparity between relevant districts, based on a comparison of the 17 th District with the average district in the state rather than a comparison of the 17 th with the three other Manhattan districts, indicates that he was seeking some harm-dilution of voting strength-independent of the alleged injury resulting from racial or ethnic classification. Since Manhattan county was established as a distinct political unit for purposes of congressional representation, ${ }^{18}$ the population disparity between Manhattan districts is a highly significant factor in finding a legislative purpose to create a predominantly white election district, while the population disparity between the 17 th and the average state district is relevant only to a determination of whether the malapportionment of a district exceeds permissible tolerances. ${ }^{19}$ Moreover, Judge Moore's opinion does not deal with

Opinion of Judge Feinberg, $211 \mathrm{~F}$. Supp. at 470 . However, state refusal to redraw the western boundary because it already suited a general purpose of creating racially homo. geneous districts can equally be inferred. In addition, the line straightening contemplated by Judge Feinberg would have resulted in a loss of 19,000 persons from the 17 th district. Record, p. 134, and might thereby have heightened the population disparity between the 17 th district and the others in Manhattan to an independently challengeable level.

16. The neighborhood added to the northeastern border of the 17th Congressional District had a population of 101,716, of whom 2,749, or 2.7\% were non-whites and Puerto Ricans. Record, pp. 124-25. The Stuyvesant Town community on the southeastern borderalmost wholly white under sanction of judicial decree, see Dorsey v. Stuyvesant Town, 299 N.Y. 512, 87 N.E.2d 541 (1949), cert. denied, 339 U.S. 981 (1950) —was the second section added to the 17 th district. Out of a total population of 22,405 , there were 105 non-whites and Puerto Ricans. Record, pp. 124-25.

17. Record, pp. $139-40$.

- 18. See note 8 supra. See also $211 \mathrm{~F}$. Supp. at 466.

19. The disparity between the population of any given New York State congressional district and the weighted average population per district at no point rises above $15 \%$, the deviance standard recommended by the American Political Science Association. See N.Y. REPoRT at 64 . The deviance between the population of the 17th Congressional District and the average state district is 7\%. $211 \mathrm{~F}$. Supp. at 464. But cf. New York Times, January 23, 1962, p. 32, col. 2 (editorial): 
the irregular, thirty-one sided configuration of the 17th congressional district, apparently because the shape of a district in which a voter is placed involves no independent harm to a voter. The serpentine configuration, however, constituted a crucial element in the plaintiff's attempt to prove that the basis of the districting was racial and ethnic.

Although there are some elements in Judge Moore's opinion which suggest a different view on the constitutional question than the one implied by the major part of it, ${ }^{20}$ it is important to note that Judge Feinberg continually characterized Judge Moore's opinion as holding the act of racial districting in and of itself constitutionally permissible. ${ }^{21}$ At no point did Judge Moore explicitly reject this contention.

Judge Feinberg, although concurring with Judge Moore in the disposition of the case, expressly rejected the proposition that race is a permissible standard by which legislatures may draw district lines:

If plaintiffs had proved that the district lines were constituted on a racial basis, the fact that plaintiffs had an undiminished right to vote in such gerrymandered districts would be irrelevant. The constitutional vice would be use by the legislature of an impermissible standard, and the harm to plaintiffs that need be shown is only that such a standard was used. ${ }^{22}$

However, he believed that the plaintiffs had failed to prove that any of the Manhattan districts had in fact been drawn on a racial basis, finding that such facts as the addition of the two predominantly white neighborhoods to the 17 th District could be explained on social and economic grounds as well as racial ones. ${ }^{23}$ Moreover, this addition, in reducing the irregularity of the contours of the 17th district, indicated that the 1961 redistricting was pursued in a "logical" and "rational" manner. ${ }^{24}$ And he found that the slight population disparity between the 17th District and the average district in the state provided insufficient support for an inference of racial gerrymandering. ${ }^{25}$ Because Judge Feinberg

A letter on this page ... defends New York's recent realignment of Congressional districts by virtually ignoring the gerrymandering and pointing to the one respect in which proper standards did rule-relative equality of population.

Representative government requires more than this. [Emphasis added.]

20. At one point, Judge Mloore suggests that "To create districts based upor equal proportions of the various races inhabiting metropolitan areas would indeed be to indulge in practices verging on the unconstitutional." $211 \mathrm{~F}$. Supp. at 468 . The statement implies that the act of racial districting might be sufficient to overturn an apportionment statute. If that is so, it is difficult to understand Judge Moore's failure to deal with those elements of the plaintiffs' case in Wright which attempted to prove racial districting on the part of the State. See text at notes 18 and 19 supra. But see note 48 infra.

21. 211 F. Supp. at 468.

22. Id. at 468 .

23. Id. at 471 .

24. Id. at 470-71.

25. Judge Feinberg's use of the average state district as a basis of comparison with the 17th Congressional District is difficult to understand, given his acceptance of the constitutional principle that racial districting is impermissible and given the fact that Manhattan may be viewed as a self-contained community insofar as its congressional districts are concerned. See text at notes 18 and 19 supra. 
regarded the obligation to disprove all permissible alternative bases for district. ing as part of the plaintiff's showing of purposive racial districting, he found that the plaintiffs had failed to establish a prima facie case.

Judge Murphy, concurring in Judge Feinberg's view of the constitutional issue, found that the plaintiff's evidence established a "prima facie case of legis. lative intent to draw congressional district lines in the 17th and 18th Districts on the basis of race and national origin."26 The state's failure to introduce any evidence rebutting this inference, he believed, warranted relief.

\section{The Equal Protection Case 27}

The kind of equal protection case presented by Wright shotld be distinguished from what may be called the more typical equal protection case, which generally poses the question of whether the persons injured or benefited by a statute represent the class of persons who should be so treated, given the purpose of the statute. ${ }^{28}$ Most statutes held violative of the equal protection clatuse

26. 211 F. Supp. at 473.

27. Compare Bickel, The Durability of Colegrove v. Green, 72 YALE L.J. 39, 43 (1962) ("Is it irrational or otherwise forbidden so to gerrymander districts that a solid negro or Puerto Rican vote is ensured, thus making certain that legislative bodies will contain members of these minority groups?"), with Emerson, Malapportionment and Judicial Pouter, 72 Y ALE L.J. 64, 74 (1962) ("[A]n apportionment system based on racial factors woutd clearly constitute a denial of equal protection.").

Cf. the statement of Mr. Justice Whittaker in Gomillion v. Lightfoot, "[F]encing Negro citizens out of Division $A$ and into Division $B$ is an unlawful segregation of races of citizens, in violation of the Equal Protection Clause of the Fourteenth Amendment." 364 U.S. at 349. The issue in Wright may be said to consist of the applicability of Mr. Justice Whittaker's principle to situations in which the harm to the groups "fenc[ed] out" is less demonstrable than it was in the Tuskeegee gerrymander.

28. The statutory purpose referred to does not suggest judicial psychoanalysis of the collective states of mind of a given set of legislators with respect to a bill at the time it was passed. It rather deals with a practice in which the courts have traditionally in. dulged; a determination of the intended thrust of a statute through a view of matcrials other than the formal words of the statute itself. See Bickel, Strathearn S.S. Co. v. Dillon -An Unpublished Opinion by Mr. Justice Brandcis, 69 HARv. L. Rev. 1177, 1203, 1204 (1956). The balance required in such endeavors is a delicate one, avoiding on the one hand the impossible ascription of a unitary motive to a diverse group of legislators while meeting, on the other, the jtidicial responsibility in equal protection cases of determining whether and to what extent the traits of parties classified reasonably relate to the public good in tended to be advanced by the enactment of the classificatory statute. See Tussman \& ten Broek, The Equal Protection of the Lawes, 37 CALIF. L. REv. 341, 344-46 (1949) [hereinafter cited as Tussman \& tenBroek]. So long as there are distinct limits to a given exercise of power-as for example a predetermined inability of state legislatures to draw district lines on the basis of race- "it becomes possible quite objectively to assess the only significant effect of a given [action] as having passed the limits; and it is then acceptable-indeed, usual-judicial diction to speak of the 'purpose' of the [action] as being constitutionally forbidden." Bicker, The Least Dangerous Branch 209 (1962).

In making determinations of legislative purpose in equal protection cases, the courts have of course not been deterred by an absence of legislative candor in enacting statutes innocuous on their face, but designed to effect a given result. See Yick Wo v. Hopkins, 118 U.S. 356, 373-74 (1886) ; Note, 70 YALE L.J. 1192, 1197 (1961). 
are either "under-inclusive"-regulating some but not all of the persons bearing the trait the statute was meant to regulate, ${ }^{29}$ or "over-inclusive"-including many persons not bearing the characteristic which the statute, given its purpose, should be concerned with. ${ }^{30}$ A challenge to this type of statute may be said to be based upon the state's mamner of classifying. But such laws have been sharply if not articulately distinguished from statutes in which the challenges may be said to be bottomed on the fact that the basis on which the state had classified was impermissible. ${ }^{31}$ Both types of equal protection cases necessarily involve a judicial determination of the purpose of the statute in question, but in "impermissible purpose" challenges like Wright, a court must determine the legitimacy of the legislative purpose rather than pass on the reasonableness of the scope of the statute.

Judge Moore appears to treat the challenge to the districting statute in Wright as belonging to the first type of equal protection problems. Thus, his opinion seems to assume that the basis of the plaintiff' complaint in WVright was their exclusion from other districts. ${ }^{32}$ If this was the equal protection argument advanced in Wright, it would justifiably be given short shrift. Challenges based on a desire to be included in or excluded from a statutory classification are generally met by a showing that the discrimination as it affects the party

29. Tussman \& terBroek at 347-49. See Missouri K. \& T. Ry. v. MFay, 194 U.S. 267, 269-70 (1904).

30. Tussman \& tenBroek at 351, 352.

31. When parties who are proper subjects of legislative regulation challenge statutes on the ground that others ought also to have been included in the statutory classificationthe challenge based on under-inclusiveness-broad judicial tolerance has been the normal response. See Lindsley v. National Carbonic Gas Co., 220 U.S. 61 (1911); Goesaert v. Clary, 335 U.S. 464 (1948) ; Williamson v. Lee Optical Co., 348 U.S. 483 (1955) ; AfCGowan v. Maryland, 366 U.S. 420 (1961). Given the inherent impossibility of drawing perfect statutes, i.e., those which include for legislative treatment only and all of those parties bearing the trait whose regulation is felt necessary, the presence of a single reasonable basis for a failure to include parties for regulatory treatment who might arguably have been placed within the reach of the challenged statute has been sufficient to sustain it. But see Skinner v. Oklahoma, 316 U.S. 535, 541 (1942) (discrimination between those included and excluded for statutory treatment "invidious" although rational).

Challenges to "over inclusive" statutes have been better received, since they are brought by parties who are affected by statutes which attempt to regulate traits the complainants do not themselves bear. Over inclusive statutes are sustained, if at all, on the basis of emergency conditions creating circumstances which may justifiably have led legislatures to be "better safe than sorry." See Tussman \& tenBroek, 351, 352. Detention statutes represent classic examples of over-inclusive classifications. Cf. Warner, The Uniform Arrest Act, 28 VA. L. REv. 315, 320-21 (1942) ; Comment, Some Proposals for Modernizing the Law of Arrests, 39 CAIIF. L. REv. 96, 99, 100 (1951).

32. Plaintiffs apparently want a higher percentage of non-whites and Puerto Rieans in the 17th. [Others] ... proclaim with equal vehemence that such a change would be violative of their rights to enjoy the redistricting as it now is. They claim, in effect, that to take a substantial number of non-whites and Puerto Ricans and to place them within the confines of a different Congressional district ... would be an Acadia-like deportation designed to dissipate and make ineffectual their votes.

211 F. Supp. at 465. 
arguing over or under inclusion is such that it could not be described as arbitrary or irrational. ${ }^{33}$ Under this argument a finding that in view of the ordinarily valid purposes of districting, it was not unreasonable for the state to have established election districts of roughly proportionate population would be determinative of the constitutional challenge. Because new district lines had to be drawn in New York in 1961 lest all its Congressmen be elected at large, it can* not be said that the legislatures had no business passing a districting statute, nor, in the absence of malapportionment, that the lines drawn were unreasonable. ${ }^{34}$ But the plaintiffs residing in the 17 th Congressional district did not object to the statute because they had not been placed in the $18 \mathrm{th}, 19 \mathrm{th}$, or 20 th districts; their objection was instead based on the fact of having been assigned at all to districts in which persons had been placed on account of their race or national origin. Thus, the constitutional objection to the apportionment statute was that the classificatory basis used by the state was impermissible. ${ }^{35}$

There is much judicial language suggesting that the use of race or national origin as a basis of statutory classification places a statute in a "constitutionally suspect" category..$^{36}$ Some formulations have indicated that race is a "constitutional irrelevance" which the state is never privileged to use, ${ }^{37}$ while most have gone no further than to create a presumptive invalidity for all statutes using racial criteria. ${ }^{38}$ Because most of the cases in the "forbidden classification" category have arisen in a context of obvious racial hostility, plaintiffs have not -at least since the landmark of Brown $v$. Board of Education ${ }^{30}$-been terribly pressed to describe the manner in which the challenged statutes have worked injury upon them. Thus, since Brown the Court has rendered per curiam de-

33. See note 29 sipra.

34. See note 19 supra.

35. Judge Moore complains that the "[p]laintiffs' theories of unconstitutionality are difficult to pin down." $211 \mathrm{~F}$. Supp. at 465 . At no time did he suggest or confront the possibility, accepted by Judges Feinberg and Murphy, of a constitutional infirmity based on the use of racial criteria by the state in the drawing of district lines.

36. Professor Bittker terms the following statement of the Court in Hirabayashi v. United States, 320 U.S. 81, 100 (1943), the "inescapable starting point" of any inquiry into statutes classifying by race:

Distinctions between citizens solely because of their ancestry are by their very naturo odious to a free people whose institutions are founded upon the doctrine of equality. Bittker, The Case of the Checker-Board Ordinance: An Expcriment in Race Relations, 71 Y ALE L.J. 1387, 1409 (1962).

See also Bolling v. Sharpe, 347 U.S. 497, 499 (1954):

Classifications based solely upon race must be scrutinized with particular care, since they are contrary to our traditions and hence constitutionally suspect.

And see Korematsu v. United States, 323 U.S. 214, 216 (1944).

37. Edwards v. California, 314 U.S. 160, 184 (1941) (concurring opinion), and see Kotch v. Board of River Port Pilot Comm'rs, 330 U.S. 552, 565-66 (1947) (dissenting opinion). See Tussman \& tenBroek at 353-55.

38. See Note, 70 YaIE L.J. 1192, 1197 (1961).

39. 347 U.S. 483 (1954). 
cisions holding racially segregated parks, ${ }^{40}$ beaches, ${ }^{11}$ golf courses, ${ }^{42}$ and so forth unconstitutional. These cases may be read to mean that any statute which openly identifies racial groups or physically separates persons of different races works an injury on members of a minority group by testifying to their inferiority and therefore is invalid. ${ }^{43}$ On the other hand, they may be read to mean that any statute which classifies on the basis of race, regardless of demonstrable immediate injury, is per se or presumptively invalid. \$\$ The applicability of these decisions under the former interpretation to the districting statute in Wright is unclear, since the actual physical separation which results from this statute seems quantitatively, if not qualitatively, distinguishable from the statutes challenged in the Brown and post-Brown cases. The only instance of clear physical segregation comes at the fleeting moment of using a voting booth every other November. Moreover, this momentary separation is not an inherent part of a districting statute. It would not be very difficult for a state to provide for integrated voting facilities while still maintaining separate political districts. However, if the principle of the Brown case and its aftermath is a broader one -i.e., that the Constitution does not tolerate distinctions based upon racial or ethnic factors, at least in the absence of extraordinary circumstances not yet known to us ${ }^{45}$ - these cases would seem to be determinative of the issue in

40. New Orleans City Park Improvemark Ass'n y. Detiege, 252 F.2d 122 (5th Cir.), aff'd per curiam, 358 U.S. 54 (1958).

40. Dawson v. Mayor \& City Council, 200 F.2d 386 (4th Cir.), affd per curiam, 350 U.S. 877 (1955).

42. Muir v. Louisville Park Theatrical Ass'n, 202 F.2d 275 (6th Cir. 1953), rev'd per curiam, 347 U.S. 971 (1954).

43. Cf. Brown v. Board of Education, 347 U.S. 483, 494 \& n.11 (1954); see Garfinkel, Social Science Evidence and the School Segregation Cases, 21 Joursis of PoLrtics 37 (1959) ; Address by Will Maslow, The Uses of Law in the Struggle for Equality, Atlantic City, N.J., December, 1954, cited in Cahn, Jurisprstdence, 30 N.Y.U.L. REv. 150, 157 In.16 (1955). See generally, The Effects of Segregation and the Consequences of Desegregation: A Social Science Statement, 37 Minv. L. REv. 427 (1953).

44. Should a plaintiff affirmatively show that he has been injured through the operation of an admitted or proven racial classification, no one can doubt his right to constitutional relief. Clearly, however, no one may claim the protection of the Constitution unless someone has been hurt. Whether the person injured must suffer injury unique to him in order to be the plaintiff involves questions of what has been loosely termed "standing," see Jaffe, Standing to Secure Judicial Review: Public Actions, 74 Harv. L. Rev. 1265, 1307-12 (1961), Jaffe, Standing to Secure Judicial Review: Prizale Actions, 75 Harv. L. REv. 255, 302-05 (1961). It is hard to contest the notion, however, that injury, ever if "in the air," is a condition precedent to a constitutional attack. See Bickel, Forcword: The Passive Virtues, The Supreme Coutrt 1960 Term, 75 HARv. L. REv. 40, 44 (1961). The question thus posed is when harm is to be presumed by operation of law simply as a result of a statute shown to classify by race. The finding of harm might be on an irrebuttable or rebuttable basis, whether in a blanket manner or only in given contexts.

45. One can imagine a scientific finding that persons of a certain pigmentation are substantially more susceptible to smallpox than other persons and a statute, based upon this finding, requiring persons with such skin to be vaccinated more frequently than members of another race: Given the validity of the scientific finding, this statute, admittedly classifying on the basis of race, would probably be unchallengeable. One may even posit a statute 
Wright, regardless of the demonstrable harms or benefits of the districting statute on the members of the minority group.

In a society where more blatant forms of segregation and public racial identifications have been means of inflicting social stigma and inferiority on minority groups, ${ }^{46}$ however, it may be that any injury which results from the employment of race as a criterion for drawing election districts is outweighed by the benevolence of a statute which guarantees the election of a Negro Congressman in a metropolitan community. Indeed, minority groups have been said to achieve their measure of full "citizenship" in America by the act of electing "one of their own" to political office. 47 Moreover, it may be that the concentration of members of a given race or ethnic group in a voting district stimulates political interest and activity on the part of the members of the minority group, who may feel that their vote really counts and their selection of a representative meaningful. Thus, the New York districting statute, assuming it is in fact based on criteria of race and nationality, may be viewed as "benign or positive discrimination"48 designed to enable Negroes and Puerto Ricans living in New York to compete on "equal" terms with whites in the political arena.40

classifying by race in the light of existing knowledge of relevant differences, although the differences that would be relevant are not readily discernible. But cf. LA. STAT. ANN. tit. 40, \$1296 (Supp. 1961) (statute requiring labeling of blood by race).

46. For a discussion of the context of the Southern segregation statutes, sce Black, The Lawfulness of the Segregation Decisions, 69 YALE L.J. 421 (1960).

47. See generally Lubeli, The Nature of Adserican Politics.

48. A theory of apportionment which places a sufficiently great premium on the ability of groups had to gain reflection of their views through the election of one of their own could ignore the presumptive harm the courts have found in all other statutes classifying by race and thus remove the gerrymander from the ambit of the principle that racial classlfications are "constitutionally suspect." See notes 36,44 supra.

It would appear that Judge Moore in his opiniow subscribes to such a "reflective" theory of apportionment. In suggesting that an effort to create a racial "mix" in a given district is constitutionally impermissible, see note 20 supra, while strongly implying that the affirmative creation of racial enclaves is permissible, see text at notes 18, 19, 21 stopra, Judgre Moore may have implied that "communal constituencies" are of a higher constitutional order than the oft-articulated principle of the irrelevance of race as a classificatory factor. Note the manner in which he distinguishes the segregation cases:

The school cases are equally irrelevant. If it is to be found that only in the 17th District is there and will there be throughout the years a Congressman who alone can speak for the electorate of Manhattan as their representative further consideration might be given to these cases. However, both major political partics would vigorously dispute a finding that a lone Congressman from New York's 17th controls or vitally influences all actions by the Congress, no matter how able any stich incumbent might be.

211 F. Supp. at $466-67$.

49. If so important a principle as the presumptive or per se invalidity of statutes based on race must yield in situations involving affirmatively segregated voting districts, the need for and benefit from such "reflective constituencies" ought to be great. Yet the most significant study and defense of electoral institutions which are designed to mute majoritarianv influence can be fairly read to argue against racial constituencies in the American context. MACKenzIe, Free Elecrions (1958) is based on a survey of electoral experiences in Europe and the new African states, warning of the dangers of "communal" elections. Al- 
If the teaching of Brozen is that racial classifications are impermissible, regardless of benefits, harms, or motives-and no cases decided since Brown are inconsistent with this reading-should this principle apply to a racially drawn districting statute, or should it be modified to allow for race in drawing political districts? If the principle cannot or should not yield, the question remains whether a court should at least treat the arrangement as an expedient compromise which, although if reconciliable with principle, should not be immediately invalidated because of its possibly benevolent effects. That is, should a court stay its hand and let racially drawn districts be until we know more about them ?50 Before these questions can be answered, a further view of the possible effects of districting on the basis of race or national origin seems necessary.

The benevolent effects of racial districting may not be the only ones, for even the most nobly motivated legislatures might in the long run be hurting the interests of the minority groups they attempt to assist through racial districting. As the plaintiffs pointed out in their brief, racially drawn districting statutes may have far more subtle consequences than segregation at the polling booths every two years:

Although a congressional election district is not as distinct an institution as a public school, park, or beach, etc., it is, nevertheless, a governmentally constructed political entity - the unit of government through which citizens participate in their National Government. As such, it necessarily spawns related groups and activities. Political campaign organizations are maintained on a permanent basis in Congressional districts; and institutional-

though recognizing that purely racial or other group constituencies may be "inevitable [for the newly formed nation], because there is great pressure on the government to concede elections, and the state of society is such that it would not be realistic to elect representatives except as representatives of separate communities," Miackenzie points out the tensions generated against the concept of national unity by the communal representation scheme first devised to save it. "People entering public life learn first to tall the languzge of communal politics, not that of national politics; communalism may thus defeat nationalism, and destroy the possibility of national self-government" Id. at 34,35 . To the extent that a sense of national unity exists in which "majorities [are] tolerant towards minorities [and] minorities ... accept without violent resistance the verdict of a majority vote" Arackenzic argues against the use of communal constituencies. Id. at 34. "Electoral engineering" is of great value to Mackenzie to avoid "destroy[ed] democracy," see id. at 94, 95, but communal constituencies are regarded as the least useful of the battery of devices available to mute absolute majority rule.

The relevant question would thus appear to be not whether the moving principle of the irrelevance of race ought to yield in the face of segregated voting districts but whether it would be expedient to strike down segregated voting districts in light of the possible advantages which may accrue from them.

50. The latter question is the only relevant one. A judgment must be made as to whether it would be viable and helpful in terms of long range interests of the isolated groups to permit the operation of racially based districts by deliberately choosing not to effectuate the principle of the invidiousness of racial classifications in such cases. This decision is a pragmatic one, rooted in the nature of, and potential abuse which may result from, racially patterned political districts. See Bicker, The Least Dasigerous Brasica 63-65 (1962). 
ized political hierarchy tends to be created and perpetuated along the line demarcated by the districting statute: and patronage and other benefits of government are distributed within the bounds of the district.

If these are among the necessary effects of racial districting-and the existence of Negro political clubs in the 18th district indicates they are-the "injury" resulting from the deprivation of the opportunity to participate in various polit ical activities with members of another race or ethnic group seems similar to those found or presumed to result from segregation of schools, parks, or golf courses. Arguably these effects, even if they do exist, should be discounted or disregarded since they are not as direct a result of the districting statute as separation was of the statutes involved in the segregation decisions. Stated differently, unlike the segregation cases, where separation was clearly the object of the legislators in enacting laws providing for all-white and all-Negro parks and schools, separate or segregated political clubs and activities may not be one of the objects the legislators wanted to achieve in drawing districts based upon race or national origin. But to maintain such distinctions as tenable is to ask a court to inquire into what has traditionally been considered tulascertainable and therefore irrelevant-namely, the subjective intent of the legislators. If the legislature in fact passed a racially drawn districting statute, then these effects are as much a part of the legislative purpose as is the election of a Negro Congressman. Therefore, they cannot be disregarded on the ground that they are indirect or that they are not included in the effects the legislature desired when it enacted a racially drawn districting statute.

Other effects, less subject to demonstration in a court room, but equally important, are also likely. The racial groups placed in separate districts may well be lulled into political torpor by the act of "allowing" them the selection of a member of their race. Whatever honor may go to "the first of his race" sitting in a legislature, it is quite possible that the interests of his group may be assumed by the community to have been satisfied by an act which has no bearing upon the advancement of his group's needs. Moreover, in places where state legislatures are not so benignly motivated toward members of a minority racial group, racially drawn districting statutes may be used not only to reflect the interests of Negroes in the legislature but, as is more likely, to maintain a concentration of racist votes in the adjacent white citizen districts. This containment function of racial gerrymanders portends a rather significant bulwark against the influence of Negro votes in places where those votes are only now beginning to be asserted. And unless surmises about the motives of legislatures are to have constitutional significance, a court would be hard pressed to distinguish between a racially drawn districting statute in New York and Mississippi. The earned election of a minority group member may well be an event meriting genuine pride by its members; the price for such pride may be high when the election is pre-arranged.

Taking a closer look at the political situation in Manhattan, for example, it seems difficult to conclude that Negroes and Puerto Ricans are not harmed by

51. Plaintiffs' Post-Trial and Reply Memorandum, p. 26. 
being lumped into a single congressional district. Although such action guarantees the election of a Negro Congressman, could it not otherwise be possible for a group representing nearly 40 per cent of the Borough population to have more influence in Congress? The last two Borough Presidents of Manhattan have been Negroes; it therefore does not seem plausible to argue that the Negroes of the borough need segregation to elect a Negro to public office. In the absence of racial and ethnic districting, could not the Negroes and Puerto Ricans become the pivotal voters in every one of the MIanhattan congressional districts and thereby multiply their chances of electing more than one non-white Congressman? In addition, arranging the racial composition of the congressional districts by such means might lead the remaining Congressmen in the borough to feel that legislative action involving the interests of Negroes are matters of unconcern, such matters having been exported to the single Congressman representing the Negro population. It also is possible that a system which lumps Negroes and Puerto Ricans into a single constituency forfeits the leadership opportunities of whichever of the two groups is in the minority in the artificially created district. There is a notable absence of political power and patronage among Puerto Ricans in New York in those areas where Negroes and Puerto Ricans live together. Courts therefore might easily be mistaken if they assume that an identity of interest exists among the different minority groups lumped together for "benign" purposes. Further, is it not possible that the voices favoring districts of a particular racial composition are those of special pleaders with vested interests in maintaining jobs they may now hold by dint of the ghetto character of the borough political structure? ${ }^{52}$

If such questions do not yield clear answers, it would seem that the inherent constitutional bias against the use of race as a device by which the state may classify ought to negative such statutes when they are admitted or proven to have been drawn on a racial basis. If states are beginning to take initial steps in the creation of what have been referred to as "benign quotas" as a means of establishing for various minorities what in a contract context has been called "equality of bargaining position,"53 it may well be that courts should not immediately strike down all statutes that are shown or admitted to have classified on a basis of race. ${ }^{54}$ Nonetheless, before judicial approval or tolerance of such experiments is granted, a more sure-footed judgment ought to be made as to the real effect of a statute than can be made about racially segregated voting districts. Unlike the districting cases in which the complaint has been that of unequal populations for like legislative districts, there is a ready ultima ratio

52. Cf. N.Y. Times, Aug. 9, 1962, p. 1, col. 6 (city ed.), N.Y. Times, Aug. 10, 1962, p. 1, col. 2 (city ed.), noted in Bickel, The Durability of Colegroz' a' Green, 72 Yale L.J. 39, 43 n.18 (1962), 211 F. Supp. at 461 (entrance of Adam Clayton Powell as party defendant-intervenor to the $W$ right suit).

53. Cf. Note, 70 Yale L.J. 126 (1960), Progress Dev. Corp. v. Afitchell, 182 F. Supp. 681, aff'd in part, rev'd in part, remanded for new trial, 286 F.2d 222 (1961) (condemation for park use of land of private developer with announced intention of selting up benign quota housing project), Bittker, stpra note 36 (hypothetical municipal ordinance forcing alternate sale of adjacent land plots to whites and Negroes).

54. See BICKEL, op. cit. supra note 50. 
by which Wright and others like it may be disposed: the irrelevance of race as a classificatory basis used by the state. Such a broad moving principle might have determined the school segregation cases, ${ }^{65}$ and more clearly the postBrowen per curiam decisions invalidating segregation in such areas as public parks, beaches, and golf courses. The principle should be dispositive of the threshhold constitutional question in Wright as well..$^{56}$

\section{The Fifteenth Amendment Case ${ }^{57}$}

In Gomillion v. Lightfoot ${ }^{58}$ the Supreme Court struck down an Alabama statute ${ }^{50}$ which had rearranged the boundary lines of the City of Tuskegee so as to exclude the vast majority of Negro voters who had previously resided within it. ${ }^{60}$ Writing for the Court in Gomillion, Mr. Justice Frankfurter implied that there had been a deprivation of voting rights of Negroes, who by virtue of the redistricting statute were denied the right to vote in Tuskegee elections. Before the statute, Negroes were permitted to vote in federal, state, county, and municipal elections. After the statute, it was said, the right to vote in municipal elections had been taken away from them. ${ }^{61}$

This does not seem to be the case, however. An Alabama statute, ${ }^{02}$ an attempted repeal of which had been defeated at the same time the challenged districting statute had been passed, ${ }^{63}$ permitted any group of 75 contiguously

55. See Cahn, Jurisprudence, 30 N.Y.U.L. REv. 150 (1955); Cahn, Jurisprudcucc, 31 N.Y.U.L. Rev. 182 (1956) ; Pollak, Social Discrimination and Judicial Intcgrity: A Reply to Professor Wechsler, 108 U. PA. L. Rev. 1 (1959). But see note 43 supra.

56. It should be noted that in Wright, the focus of plaintiffs' case was on the predominantly white 17th Congressional District, with the argument advanced that it was deliberately kept smaller to insulate a predicted Caucasion minority from a growing Negro borough population. If that be true, whatever benevolence the statute might have is thus for the protection of whites from Negroes, a purpose hardly in line with the suggested justification of benign quotas: the advancement of the interests of those groups temporarily disadvantaged by reason of historical discrimination practiced against them. Absent a subordination of the principle of the irrelevance of race to that of the need for racially "reflective" constituencies, see note 43 supra, the Manhattan situation is thus less deserving of judicial tenderness than other "benign" racial districts might arguably be.

57. See statement of Mr. Justice Douglas in Baker v. Carr:

Race, color or previous condition of servitude are impermissible standards by reason of the Fifteenth Amendment, and that alone is sufficient to explain Gomilliou v. Lightfoot.

369 U.S. at 244.

58. 364 U.S. $339(1960)$.

59. Laws Ala. 1957, p. 185, Local Act No. 140.

60. There were 400 registered Negro voters living in Tuskeegee prior to the passage of Act 140. All but five were excized from the newly formed municipality with no registered white voters being eliminated. The city had 6,707 residents, of which 5,397 were Negro prior to the passage of the Act. The new city had a population of $1,750,75 \%$ of whom were white. Lucas, Dragon in the Thicket: A Perusal of Gomillion v. Lightfoot, 1961 SUpreme Court Review 194, 195-96. [Hereinafter cited as Lucas.]

61. 364 U.S. at 341.

62. Ala. Code tit. 37, § 10 (1958).

63. Lucas at 210-11. The analysis under the fifteenth amendment is basically that of Dean Lucas and was adopted by Judge Feinberg at trial, 211 F. Supp. at 468-69. 
domiciled Alabama voters to form a municipality of their own by filing a motion with the clerk of the county court. Such action, which would grant the parties in the newly formed cities all the rights accruing to municipalities in the state, could be taken by voters residing in unincorporated areas. Therefore the excluded voters, although nominally deprived of the right they previously had to vote in municipal elections, could have reacquired this right, albeit in a different municipality, by the act of filing a motion with the county court.

Although the redistricting statute in Gomillion did not absolutely deprive these Negroes of voting rights in municipal elections, it does appear that the Negro voters because of their race had been removed from a municipality which was more amenable to political representation and municipal services. ${ }^{\text {of }}$ Alternatively, the white voters because of their race were given a municipality not built up entirely by their tax moneys. Although it is not clear that these facts were fully argued to the Court in Gomillion, ${ }^{\circ 5}$ it is arguable that the decision rested upon something more than the nominal deprivation of a pre-existing right to vote; rather the decision may be read to have held that movement of the Tuskeegee Negroes into a less potentially serviceable constituency on grounds of race constituted an abridgment of the right to vote under the fifteenth amendment. ${ }^{66}$ If this is what the Court in fact held in Gomillion, the scope of the fifteenth amendment's protection of the right to vote would include not only a right to exercise a franchise in any election but also a right to all the benefits and power which were formerly an inseparable part of the franchise.

Given this reading of Gomillion and its broad interpretation of "vote," as that term is used in the fifteenth amendment, the 12 per cent disparity in voting strength between voters of the Negro and the white Manhattan congressional districts, although probably not exceeding permissible tolerances under the fourteenth amendment, becomes highly significant. If it can be established that the district lines in Manhattan were drawn along racial lines, then the lesser voting strength of the residents of the non-white and Puerto Rican 18th Congressional District may be said to have been caused by reason of their race. May members of minority groups be permitted a measurable, albeit small, dilution of their vote in order to assure representation by one of their own kind? Under the above interpretation of Gomillion, this question would probably be answered in the negative. Were the 17th Congressional District equal in population size to all others in Manhattan, under the above analysis no fifteenth amendment case could be made. ${ }^{67}$ However, the incremental voting muscle

64. Lucas at 210-13.

65. Id. at 213.

66. See id. at 233-34. U.S. Const. amend. XV, $\S 1$ reads as follows:

The right of citizens of the United States to vote shall not be denied or abridged by the United States or any State on account of race, color or previous condition of servitude-

67. The analysis presented herein is midway between that of Mir. Justice Douglas, who would find a fifteenth amendment violation on the sole strength of racial districting, sce note 57 supra, and that of Mr. Justice Frankfurter who articulated the test in terms of nothing less than a denial of a vote, see note 61 supra. 
given certain voters because they are white, as well as the concomitant subtraction of power from Negro and Puerto Rican voters tends to make out a case under the fifteenth amendment. And it would appear that this result under the fifteenth amendment would not be different even if it were constitutionally permissible for legislatures to establish "benign" voting districts under the fourteenth amendment.

\section{Some Problems of Proof}

If either the fourteenth or fifteenth amendments proscribe voting districts based on racial criteria, the crucial issue in Wright becomes one of proof. As Judge Murphy pointed out in his dissent, there was no "oral or written statement made by the legislature either in the form of a committee report or from the manager of the bill, or statements from the legislators themselves" showing an express legislative intent to establish districts on a racial basis. ${ }^{08}$ No public hearings were held on the bill, which was adopted by a straight party line vote.

Even in the absence of such testimony, however, courts must ascertain what may loosely be called the legislative intent. If one enunciates a test based solely on the de facto nature, or effect of the statute, rather than the legislative purpose which generated its passage, the problem can appear delusively simple. Such an approach finds the constitutional evil in the fact that people bearing a given trait-such as race-find themselves grouped together after the passage of the statute, rather than in the fact that the legislature has used a forbidden criterion. This approach tends to ignore the possibility of voluntary groupings of people with like traits. Moreover, assuming that racial homogeneity is bad if it is the result of a districting statute, the question must be asked as to how much homogeneity is needed to discredit the statute. A mathematical quagmire looms for courts forced to decide whether a given degree of racial homogeneity - for example the 94.9 per cent and 86.6 per cent in two of the $W$ right districts -is to be given suffioient force to decide the case in and of itself, or even create a prima facie case. If the quantum of racial homogeneity is to be the principal determinative fact in these cases, legislatures may immunize districts purposely drawn to reflect racial characteristics. Further, if the fact of racial homogeneity is regarded as the constitutional evil, state legislatures are forced to employ racial criteria in drawing district lines so as to avoid a constitutionally impermissible, or even constitutionally suspect, grouping of members of the same race. Thus under the "effects" test the use of factors such as race becomes mandatory rather than forbidden. Since the operative principle in these cases is that race is a constitutional irrelevance, ${ }^{09}$ this result seems anomalots. Moreover, the difficulties imposed on legislatures by such an approach multiply as the number of impermissible groupings increases. For example, if homogeneity of members of a political party or an economic class are regarded along with race as invalidating factors or groupings, legislatures in drawing district lines will be forced to strike proper "mixes" of citizens with respect to political affiliation

68. 211 F. Supp. at 473.

69. See note 48 supra. 
and economic status as well as race in order to immunize their statutes from judicial attack.

The divergence in approaches is perhaps best put in terms of the question of whether the "segregation" condemned in Brown and the post-Brown per curiam decisions is a noun or verb. The issue can be seen in the northern school segregation cases, in which two courts, while reaching the same result, approached the Brown decision from different perspectives. In the case of Branche v. Board of Education of Hempstead ${ }^{\circ 0}$ Judge Dooling suggested that school boards are under a duty affirmatively to avoid even accidental racial groupings or, in other words, are under a duty to integrate school districts. He denied the board's motion for summary judgment, despite a failure on the plaintiffs' part to counter the board's allegation that:

[T] hey ... have not by any design, pattern of conduct, or contrivance created or maintained segregated education ... . because the distribution of white and Negro children ... is the result solely of the residential pattern of the district; that the school boundary zones are not "gerrymandered" but drawn solely on the basis of the considerations proper to the design of school zones and that the schools are, similarly, properly located in the zones. $^{71}$

The court responded:

[I] is not enough to show that residence accounts for the fact of segregation and to contend that therefore the segregation is ineluctable. The effort to mitigate the consequent educational inadequacy has not been made and to forego that effort to deal with the inadequacy is to impose it in the absence of a conclusive demonstration that no circumstantially possible effort can effect any significant mitigation. What is involved here is not convenience but constitutional interests. ${ }^{72}$

This is distinctly a minority approach even for school district cases ${ }^{33}$-where the harm visited is clearly more immediate and apparent than that caused by segregated voting districts.

The more orthodox approach was taken in Taylor v. Board of Education of New Rochelle. ${ }^{74}$ Suit was brought to enjoin a board of education from proceeding with the construction of a new school in a segregated district, and from refusing to allow Negro students to transfer to other school districts. The Second Circuit upheld a decision for the plaintiffs on the basis of testimony that thirty years prior to the litigation, the board of education had made certain changes in the school districting master plan in order to guarantee an almost all Negro make-up within the challenged district. The court found that by its inertia the current school board had continued the original purposive act

70. 204 F. Supp. 150 (1962).

71. Id. at 151 .

72. Id. at 153.

73. See, e.g., Avery v. Wichita Falls Independent School Dist., 241 F.2d 230, 233 (5th Cir. 1957) ; Borders v. Rippy, 247 F.2d 268, 271 (3d Cir. 1957); Allen v. County School Bd., 249 F.2d 462, 465 (4th Cir. 1957); Briggs v. Elliott, 132 F. Supp. 776, 777 (E.D. S.C. 1955).

74. 191 F. Supp. 181 (S.D.N.Y. 1961), aff'd, 294 F.2d 36 (2d Cir. 1961). 
and should therefore be held responsible to repair the damage generated by it.76 Implicit in this ruling in Taylor is that de facto segregation whose causes might be myriad is not per se unconstitutional. Other courts have refused to overthrow districts or enjoin future school board actions which admittedly have the effect of increasing racial homogeneity on the ground that there was no showing that race was a part of the legislative purpose. ${ }^{76}$

In Norris $v$. Alabama ${ }^{77}$ and Hernandez $v$. Texas, ${ }^{78}$ the Supreme Court determined that there was systematic exclusion of Negroes from jury service through the use of a de facto "effects" test. Thus a prima facie case was held to have been established solely on the strength of a comparison between the number of minority group members residing within a given community and the number of members of that group who had served on its juries. In both cases, the unrebutted evidence was that no members of the complaining minority groups had ever served on the juries of their respective communities, although substantial numbers of them resided in those communities. Such a showing, said the Court, established a prima facie case of systematic jury exclusion, and required the state either to rebut the plaintiffs' evidence of the infrequency of selection of minority group members, or to suggest alternative explanations of these facts.

In Norris and Hernandez, however, a prima facie case could be based solely on a showing of the de facto situation because only two logical inferences were possible-systematic exclusion of members of the minority group from the jury rolls or no such exclusion. By their showing that no members of the minority group had served on a jury, the plaintiffs created a clear inference of systematic exclusion. Chance-the only other possible explanation of the figures-is so clearly unlikely that a prima facie case was established. In Wright and other gerrymander challenges, however, a showing even of 100 per cent racial homogeneity in a challenged district still leaves the logical possibility that the situlation may be explained on many other and permissible bases. The probability or improbability of the alternative explanations cannot be clearly established without some empirical investigation.

An inquiry into whether the legislature purposefully drew district lines on a racial basis need not be an exercise in metaphysics or group psychoanalysis. The purpose test would impose a burden on the plaintiff to show that the use of a racial criterion is a more reasonable inference than that of other permissible factors which might have been used. The question then arises as to which permissible factors must be shown to be a less likely basis than the impermissible one. A challenge to a districting statute might be said to require the plaintiff to rebut any possible basis that is constitutionally permissible. This seems to be the view of Judge Feinberg, who implied that refusal to find a prima facie case was based on both the failure of the plaintiffs to fulfill their perstuasion

75. 191 F. Supp. at 192-93, 294 F.2d at 38.

76. See, e.g., Henry v. Godsell, 165 F. Supp. 87, 91 (E.D. Mich. 1958).

77. 294 U.S. 587 (1935).

78. 347 U.S. 475 (1954). 
burden as to the alternative purposes they did try to prove were less likely than race; and on their failure to meet their production burden as to other possible bases on which the districting statute might have been drawn. Thus, he stated that the plaintiffs failed to disprove the possibility of social and economic groupings, ${ }^{79}$ although the facts on which this inference was based were not alleged by either the plaintiff or defendant.

Arguably this requirement that the plaintiff demonstrate that the impermissible factor more plausibly explains the challenged statute than any permissible factors is desirable, although the court or the defendant should be under some obligation to suggest factors that the moving party must rebut. Such a procedure has the advantage of forcing the court to make articulate and therefore readily appealable its judgments as to whether given districting bases are permissible. For example, had the plaintiffs in $W$ right been requested by the court to prove that the factor of political affiliation was not a more plausible basis of the configuration of the 17th Congressional District than race, an appeal could have been taken on the issue of whether states may draw district lines on the basis of politics. ${ }^{80}$ The same might have been done on the issue of wealth, a basis which may well in fact be a more plausible reason for the shape of the 17th district, long termed the "silk stocking district."

On the other hand, requiring a plaintiff to disprove all other permissible bases seems to impose on him the impossible task of rebutting all phantom bases on which a statute might have been drawn. Without requiring a state to introduce evidence tending to show some other explanation for the statute, a court could not generally determine whether other alleged bases are plausible. And without this determination the moving party in districting cases might never establish a prima facie case. In other words, at some point the burden of introducing evidence to substantiate the claim of other permissible bases of the challenged statute must shift to the state. It would seem that this point should be reached when the plaintiffs have established that race is the more likely basis than the more commonly known and expected bases of districting. In Wright, the plaintiffs showed race to be a more plausible explanation of the 17 th Congressional District than at least three apparently permissible legislative purposes: the objective of constructing districts in a compact fashion along rea-

79. $211 \mathrm{~F}$. Supp. at 471. A discussion of the constitutionality of district lines drawn on the basis of political affiliation is outside the scope of this Note. What is important is that a judicial determination can independently be made on the merits of the permissibility of politics as a factor in the apportionment. For a discussion of the legitimacy of political factors in apportionment see Comment, Baker v. Carr and Legislatize Apportionments: $A$ Problem of Standards, 72 Yale L.J. 968, 999 (1963).

80. After the close of trial in Wright all parties were requested to stipulate certain facts with respect to the political affiliations of parties in the borderline census tracts of the 17th Congressional District. The plaintiffs refused to accede, claiming in the alternative that evidence as to political affiliation was irrelevant and that, if relevant, a formal reopening of the trial was necessary so that all facts with respect to political affiliations could be brought out. Plaintiffs' Memorandum in Response to Request for Stipulation, pp. 2-13.

Evidence as to political alignments in Mranhattan was therefore not considered by the trial panel. 211 F. Supp. at 470 n.11. 
sonably geometric lines; the objective of constructing districts reflecting preexisting political institutions; and the objective of constructing a district reflecting natural geographic boundaries. This proof should have been found to establish a prima facie case, for it does not appear that there are, nor did Judge Feinberg find, other clearly permissible bases for districting that the plaintiffs failed to disprove. Race was therefore the more likely inference. The burden of alleging and proving the factors of politics and wealth, as Judge Murphy suga gested, should have been on the defendants. If these factors were established, other, perhaps distinct, constitutional questions would have been posed.

\section{Conclusion}

A reversal of Wright need not be seismic in its implications for the judicial system. Because of the proof problems inherent in making a showing of purposeful use of impermissible factors, a legislature wishing to construct voting districts along racial lines could mute the harshness of its gerrymanders and thus probably avoid judicial invalidation of such legislation. So long as responsibility for legislative districting remains vested in the legislatures, courts are not ultimately capable of thwarting legislative designs to mold apportionment schemes to the benefit or detriment of whichever groups they so choose to affect. Nor should they be. The judicial function in cases like Wright need be no more than to invalidate those acts that are flagrant in their tuse of impermissible criteria and thus to inhibit future legislative use of such factors.

Courts dealing with gerrymander challenges are not faced with the institttional difficulties which plague attempts to resolve challenges to equally weighted districts having sizeable population disparities. In the latter instance, in the absence of any constitutionally enforceable standard setting down a tolerance for population disparities, courts may in some measure be led to permit their likes and dislikes for particular fact situations be dispositive. ${ }^{81}$ Courts may thus "bless ... expedient arrangements that legislatures will make," and validate objectionable apportionment schemes which are nonetheless held to pass constitutional muster. ${ }^{82}$ No such problems attach to the Wright litigation or challenges involving districting allegedly drawn on any impermissible basis. In such cases the nature of the proceeding is radically different. Plaintiffs are obligated to satisfy the trier of fact of a factual question - that the state has tused criterin forbidden to it. And prior judicial decisions have generally established that the criteria are impermissible. The problems involved in proving such use and in determining the permissibility of the various possible bases of districting statutes are of a sort which have historically been dealt with by the courts under

81. The classic objection to extended future use of Baker $v$. Carr is the felt absence of a fixed polestar towards which courts can gravitate. See Bickel, Forcword: The Passine Virtues, The Supreme Court, 1960 Term, 75 HaRv. L. REv. 40 (1961); Israel, On Charting A Course Through the Mathematical Quagmire: The Future of Baker v. Carr, 61 Mirch. L. Rev. 107, 130-46 (1962). Cf. McCloskey, Foreword: The Reapportionment Casc, the Supreme Court, 1961 Term, 67-74 (1962). But see Comment, Bakcr v. Carr and Lctgislative Apportionments: A Problem of Standards, 72 YALE L.J. 968 (1963).

82. Bickel, The Durability of Colegrove v. Green, 72 YALE L.J. 39, 44 (1962). 
the equal protection clause and the fifteenth amendment. Indeed, the $W$ right litigation itself may eventuate in findings as to the permissibility of the use of such factors as wealth and political affiliation by legislatures in drawing legislative district lines. 83

In light of the limited nature of the judicial relief ultimately available, it would be unfortunate if none were afforded in cases like Wright. For there the gerrymander could hardly be less patent. Should the Wright decision be sustained, states could with impunity draw legislative district lines on whatever bases they chose, so long as they kept the population disparities between equally weighted districts within constitutional bounds. The point has been aptly made that so long as the principle of "equal representation" remains the motive force behind Baker v. Carr, ${ }^{84}$ a failure to deal with the problems of the gerrymander may give the Baker decision the thrust of "one half a pair of pliers." Given the greater facility with which courts can deal with the gerrymander problem, as well as the general public expectance and demand for judicial support ${ }^{86}$ in a field where reform, if any, is to come from the courts, ${ }^{87}$ abstinence in $W$ right would indeed be unfortunate.

83. There is much to suggest that the district lines in Manhattan were drawn on the basis of politics. The defendant-intervenors in the case so asserted as an affirmative dciense of the apportionment.

84. Such was the standard suggested by the government in Baker i. Corr.

85. Neal, Baker v. Carr: Politics in Scarch of Lazw, 1962 Sur. CT. Rev. 252, 275-78 (1962). Dean Neal's analysis is extremely revealing in terms of logical imperatives imposed on the courts for dealing with gerrymander cases given an involvement in malapportionment cases. His suggestion is that the courts recede from the entire area of apportionment challenges, a suggestion hardly likely to find much favor with the courts. So long as malapportionment challenges similar to Baker v. Carr are dealt with, however, Dean Ncal is persuasive in suggesting the need to find some manageable basis on which gerrymander cases can be dealt with.

86. See, e.g., Ascoli, Reporter's Notes, The Reporter, April 1-12, 1962, p. 12.

87. See generally Lewis, Legislative Apportionment and the Federal Courts, 71 Hasv.

L. REv. 1057 (1958). 